\title{
Antigenotoxic, and anticytotoxic activities of an ethanolic extract of Lafoensia pacari (Lythraceae) stem bark in bacteria and mice
}

\author{
D.C.S. Lima ${ }^{1}$, C.R. Silva ${ }^{1}$, B.L. Sampaio ${ }^{2}$, J.R. de Paula ${ }^{2}$ and \\ L. Chen-Chen ${ }^{1}$ \\ ${ }^{1}$ Departamento de Biologia Geral, Instituto de Ciências Biológicas, \\ Universidade Federal de Goiás, Goiânia, GO, Brasil \\ ${ }^{2}$ Faculdade de Farmácia, Universidade Federal de Goiás, Goiânia, GO, Brasil \\ Corresponding author: L. Chen-Chen \\ E-mail: chenleego@yahoo.com.br
}

Genet. Mol. Res. 12 (3): 3887-3896 (2013)

Received January 26, 2013

Accepted July 29, 2013

Published September 23, 2013

DOI http://dx.doi.org/10.4238/2013.September.23.7

\begin{abstract}
Lafoensia pacari (Lythraceae), popularly known in Brazil as "pacari", is a small tree native to the Cerrado that is used in folk medicine to treat cancer and as an anti-inflammatory and cicatrizing agent. We evaluated the genotoxic, cytotoxic, antigenotoxic, and anticytotoxic activities of an ethanol extract of L. pacari stem bark (EESB) using the Ames test and the mouse bone marrow micronucleus test. In the Ames test, EESB did not significantly increase the number of $\mathrm{His}^{+}$revertants in Salmonella typhimurium tester strains TA98 and TA100 at all doses, demonstrating lack of mutagenicity. Only the highest dose of EESB significantly increased the micronucleated polychromatic erythrocyte frequency in the micronucleus test, indicating mild genotoxicity. EESB produced a mutagenic index lower than the negative control in the Ames test. In the micronucleus test, at all doses, EESB caused a significant decrease in the polychromatic/normochromatic erythrocyte ratio (PCE/NCE) at $24 \mathrm{~h}$ compared with the negative control. EESB co-administered together with the respective positive control caused
\end{abstract}


a significant decrease in the number of $\mathrm{His}^{+}$revertant colonies in the Ames test and in the frequency of micronucleated polychromatic erythrocytes in the micronucleus test, demonstrating a DNA protector effect. EESB co-administered with mitomycin $\mathrm{C}$ significantly increased the PCE/NCE ratio at all doses, showing an anticytotoxic effect. We conclude that EESB has antigenotoxic and anticytotoxic properties.

Key words: Lafoensia pacari; Pacari; Antigenotoxicity; Bacteria; Mice; Anticytotoxicity;

\section{INTRODUCTION}

Brazil is a country that has the greatest biodiversity on the planet. Recent studies indicate that between 170,000 and 210,000 Brazilian species are known to science, approximately $13 \%$ of the world's biota (Nascimento et al., 2011). A large portion of this biodiversity is found in the Brazilian Cerrado, a region that covers approximately $25 \%$ of the total land area of the country and is characterized by a gradient of grassland to savanna and forest formations, as well as high richness of animal and plant species (Ribeiro et al., 2011).

The Cerrado is home to more than 7000 native species of vascular plants and many of them have been widely used in folk medicine by local people to treat a variety of diseases (Hiruma-Lima et al., 2006). In fact, several plants provide health benefits by exhibiting antihemorrhagic (Mazzolin et al., 2010), antioxidant (Souza et al., 2012), and antimutagenic activities (Vilar et al., 2009b). Moreover, several studies have demonstrated that numerous active compounds from Brazilian Cerrado plants show promising biological properties for cancer therapy (de Mesquita et al., 2009).

However, many plants can also pose health risks since they exhibit cytotoxic (Silva et al., 2012), genotoxic (Vilar et al., 2009a), and mutagenic activities (Ferreira et al., 2009). Long-term use of genotoxic compounds can cause DNA damage and promote the development of degenerative diseases, such as cancer (Santos et al., 2011).

Lafoensia pacari A. St.-Hil., popularly known in Brazil as "pacari", "dedaleiro", "didal" and "mangabeira-brava", is a medicinal plant of the family Lythraceae that is widely used as an antipyretic, wound healing, anti-inflammatory, and antidiarrheal agent, as well as in the treatment of gastritis and cancer (Sampaio et al., 2011). Infusion or maceration in white wine or in water for oral administration are the most common methods for preparing a remedy with this plant (Solon et al., 2000; Galdino et al., 2009).

The phytochemical analysis of $L$. pacari has revealed that this species contains phenolic compounds, mainly tannins and flavonoids (Solon et al., 2000; Galdino et al., 2009; Sampaio et al., 2011). It also possesses many biological properties, such as free radical scavenging (Solon et al., 2000), antidyspeptic (da Mota et al., 2006), anti-inflammatory (Rogerio et al., 2008), antidepressant-like (Galdino et al., 2009), and antifungal (Silva Junior et al., 2010) activities. Nevertheless, so far and to the best of our knowledge, no studies of the genotoxic and antigenotoxic effects of $L$. pacari have been published.

Due to the broad biological activity of $L$. pacari and aiming to contribute to the safe and efficient use of this plant in folk medicine, the objective of the present study was to evaluate the genotoxic, cytotoxic, and protective effects of the ethanolic extract from L. pacari stem 
bark (EESB) using the Ames test and the mouse bone marrow micronucleus test.

The Ames mutagenicity test uses several different tester strains of Salmonella typhimurium to measure two classes of gene mutation, namely base pair substitution and small frameshifts (Mortelmans and Zeiger, 2000). This test serves as a model for predicting and understanding the toxicological properties of the test substance (Claxton et al., 2010).

The micronucleus test is widely used to detect clastogenicity (chromosome breakage) and aneugenicity (chromosome lagging resulting from damage to the mitotic apparatus), and therefore, it has been the primary in vivo test accepted and recommended by the regulatory agencies around the globe for product safety assessment (Krishna and Hayashi, 2000).

\section{MATERIAL AND METHODS}

\section{Plant material}

Samples of $L$. pacari stem bark were collected in Urutaí (17²2'04.4"S; 48 $12^{\prime} 19.6^{\prime}$ 'W), in the state of Goiás, Brazil. The air-dried and powdered stem bark was exhaustively extracted with $95 \%$ aqueous ethanol at room temperature for three days, and the resultant alcohol solution was filtered and concentrated to dryness. The EESB powder obtained was transferred to glass flasks filled to the top and kept at $5^{\circ} \mathrm{C}$ until the moment of use. For the Ames test, the EESB powder was dissolved in sterile distilled water and dimethyl sulfoxide (DMSO) $(3: 1)$, whereas for the micronucleus test it was dissolved in DMSO alone.

\section{Ames test - Salmonella mutagenicity assay}

\section{Strains}

Salmonella typhimurium tester strains TA98 and TA100 were kindly supplied by the Laboratório de Radiobiologia Molecular of the Instituto de Biofísica Carlos Chagas Filho, Universidade Federal do Rio de Janeiro, Rio de Janeiro, Brazil.

\section{Experimental procedure}

The $S$. typhimurium histidine point mutation assay proposed by Maron and Ames (1983) was followed. A $0.1-\mathrm{mL}$ aliquot of bacterial suspension $\left(1-2 \times 10^{9}\right.$ cells $\left./ \mathrm{mL}\right)$ of each strain (TA98 and TA100) was incubated with $0.5,1.0,2.0$, and $4.0 \mathrm{mg} /$ plate EESB at $37^{\circ} \mathrm{C}$ for $25 \mathrm{~min}$. A $2.0-\mathrm{mL}$ aliquot of top agar $(0.6 \%$ Difco agar, $0.5 \% \mathrm{NaCl}, 50 \mu \mathrm{M}$ L-histidine and $50 \mu \mathrm{M}$ biotin, at $45^{\circ} \mathrm{C}$ ) was added to the test tubes and poured onto Petri dishes containing minimal agar medium (1.5\% agar, $2 \%$ glucose, and Vogel-Bonner medium E). Each assay was performed three times in triplicate and included a negative [100 $\mu \mathrm{L}$ sterile distilled water and DMSO (3:1)] and a positive control $[0.5 \mu \mathrm{g}$ 4-nitroquinoline 1-oxide (4-NQO) per plate for TA98 and $1.5 \mu \mathrm{g}$ sodium azide for TA100]. For the evaluation of antimutagenicity, doses of $0.5,1.0,2.0$ and $4.0 \mathrm{mg} /$ plate EESB were incubated and combined with their respective positive controls. After incubation at $37^{\circ} \mathrm{C}$ for $48 \mathrm{~h}$, the $\mathrm{His}^{+}$revertant colonies were counted. 


\section{Statistical analysis}

The softwares Excel and/or Sigma Stat 3.5 were used in all analyses. All the results were tabulated and the experimental values were expressed as mean \pm standard deviation (SD). The data obtained from the experiments of mutagenicity were evaluated by ANOVA and Tukey's test for difference of means. The magnitude of the mutagenicity induction was measured by the mutagenic index (MI), calculated as the ratio between the number of colonies in the test treatment and the number of colonies in the negative control treatment. The inhibition percentage of mutagenicity (IP) induced by each mutagen was calculated in relation to the number of revertant colonies obtained in the control group treated with the mutagen alone, using the following formula (Sghaier et al., 2011):

$$
\operatorname{IP}(\%)=\left[1-\left(\frac{\text { number of revertants on test plates }-\mathrm{SR}}{\text { number of revertants on positive control plates }-\mathrm{SR}}\right)\right] \times 100
$$

test plates: plates incubated with mutagen and extract control plates: plates incubated with the mutagen alone

SR: spontaneous revertants (test strains incubated in the absence of extract and mutagen)

\section{Mouse bone marrow micronucleus test}

\section{Animals}

This study was approved by the Human and Animal Research Ethics Committee of the Universidade Federal de Goiás (CoEP/UFG No. 224/2011). Healthy, young male adult (8-12 weeks) outbred mice (Mus musculus, Swiss Webster), weighing 25-30 g, obtained from the Central Animal House of the Universidade Federal de Goiás were used in the study. All animals were brought to the laboratory five days before the experiments and housed in plastic cages $(40 \times 30 \times 16 \mathrm{~cm})$ at $24 \pm$ $2^{\circ} \mathrm{C}$ and $55 \pm 10 \%$ humidity, with a light-dark natural cycle of $12 \mathrm{~h}$. Food (appropriate commercial rodent diet Labina, Ecibra Ltda., Santo Amaro, SP, Brazil) and water were given ad libitum.

\section{Experimental procedure}

The experiments were performed according to von Ledebur and Schmid (1973). For the evaluation of genotoxicity, three doses of $\operatorname{EESB}(100,200$, and $300 \mathrm{mg} / \mathrm{kg}$ body weight $)$ were orally administered to groups of five animals for each treatment. The same doses were administered in combination with mitomycin C (MMC, 4 mg/kg i.p., Lot No. 237AEL, Bristol, Meyers Squibb, São Paulo, SP, Brazil) to groups of five animals for each treatment for the evaluation of antigenotoxicity. A positive control group (MMC) and a negative control group (DMSO) were also included.

The animals were euthanized by cervical dislocation 24 or $48 \mathrm{~h}$ after the administration of EESB, and their bone marrow cells were flushed from both femurs in fetal bovine serum (FBS, Lot No. 30721063, Laborclin, Campinas, SP, Brazil). After centrifugation (300 $\mathrm{x} g, 5 \mathrm{~min}$ ), the bone marrow cells were smeared on glass slides, coded for blind analysis, air-dried, and fixed with absolute methanol $\left(\mathrm{CH}_{4} \mathrm{O}\right.$, Lot No. 55026, Synth, Diadema, SP, Brazil) for $5 \mathrm{~min}$ at room temperature. The smears were stained with Giemsa (Lot No. 1081, Doles, Goiânia, GO, Brazil), dibasic sodium phosphate (Na2HPO4·12H2O, Lot No. 982162 , 
Vetec, Duque de Caxias, RJ, Brazil) and monobasic sodium phosphate $\left(\mathrm{NaH}_{2} \mathrm{PO}_{4} \cdot \mathrm{H}_{2} \mathrm{O}\right.$, Lot No. 983831, Vetec) to detect micronucleated polychromatic erythrocytes (MNPCE).

For each animal, four slides were prepared and 2000 polychromatic erythrocytes (PCE) were counted to determine the frequency of MNPCE using light microscope (Olympus BH-2 10 x 100, Tokyo, Japan). Genotoxicity and antigenotoxicity were assessed by the frequency of MNPCE, whereas cytotoxicity and anticytotoxicity were evaluated by the PCE and normochromatic erythrocytes (NCE) ratio (PCE/NCE).

\section{Statistical analysis}

To analyze the genotoxic activity of EESB using the mouse bone marrow micronucleus test, the frequencies of MNPCE of the treated groups were compared with the results obtained for the negative control groups using one-way ANOVA. $\mathrm{P}<0.05$ was considered indicative of significance. To assess its cytotoxicity, the PCE/NCE ratio obtained at different concentrations of EESB was compared with the negative control by the chi-square test $\left(\chi^{2}\right)$. P $<0.05$ was considered indicative of significance.

\section{RESULTS}

\section{Ames test - Salmonella mutagenicity assay}

The results of the mutagenic and antimutagenic evaluation are presented in Table 1. All results were from three independent experiments carried out in triplicate. The data obtained for the positive and negative control groups indicate that the strains were in agreement with the guidance established both by Maron and Ames (1983) and Mortelmans and Zeiger (2000).

Table 1. Means \pm standard deviation (SD) of histidine revertant colonies (obtained from three independent experiments carried out in triplicate), mutagenic index (MI), and inhibition percentage of mutagenicity (IP) for two tester strains of Salmonella typhimurium, TA98 and TA100, after treatment with different doses of the ethanolic extract from Lafoensia pacari stem bark (EESB).

\begin{tabular}{|c|c|c|c|c|c|c|c|c|}
\hline \multirow[t]{3}{*}{ Treatment } & \multicolumn{4}{|c|}{ Mutagenicity } & \multicolumn{4}{|c|}{ Antimutagenicity } \\
\hline & \multicolumn{2}{|l|}{ TA 98} & \multicolumn{2}{|l|}{ TA 100} & \multicolumn{2}{|l|}{ TA 98} & \multicolumn{2}{|l|}{ TA 100} \\
\hline & Means $\pm \mathrm{SD}$ & MI & Means \pm SD & MI & Means \pm SD & IP $(\%)$ & Means \pm SD & IP $(\%)$ \\
\hline Negative control ${ }^{1}$ & $42.67 \pm 8.51^{\mathrm{b}}$ & 1.00 & $215.67 \pm 44.74^{b}$ & 1.00 & $42.67 \pm 10.26^{\mathrm{d}}$ & - & $249.67 \pm 23.46^{\mathrm{d}}$ & - \\
\hline Positive control $^{2}$ & $439.00 \pm 11.27^{\mathrm{a}}$ & 10.29 & $2175.67 \pm 147.19^{a}$ & 10.09 & $511.67 \pm 45.65^{\mathrm{c}}$ & - & $2090.00 \pm 66.91^{\mathrm{c}}$ & - \\
\hline EESB $0.5 \mathrm{mg} /$ plate & $39.67 \pm 8.51^{\mathrm{b}}$ & 0.93 & $229.33 \pm 33.86^{\mathrm{b}}$ & 1.06 & $380.67 \pm 14.05^{\mathrm{d}}$ & 28 & $1319.33 \pm 23.44^{\mathrm{d}}$ & 42 \\
\hline EESB $1.0 \mathrm{mg} /$ plate & $32.67 \pm 7.37^{\mathrm{b}}$ & 0.76 & $242.67 \pm 52.16^{\mathrm{b}}$ & 1.12 & $306.00 \pm 31.05^{\mathrm{d}}$ & 44 & $1273.33 \pm 163.13^{\mathrm{d}}$ & 44 \\
\hline EESB $2.0 \mathrm{mg} /$ plate & $30.33 \pm 6.51^{\mathrm{b}}$ & 0.71 & $201.67 \pm 48.52^{\mathrm{b}}$ & 0.93 & $137.33 \pm 2.31^{\mathrm{d}}$ & 80 & $1097.33 \pm 70.07^{\mathrm{d}}$ & 54 \\
\hline EESB $4.0 \mathrm{mg} /$ plate & $25.00 \pm 1.00^{\mathrm{b}}$ & 0.58 & $141.67 \pm 6.43^{\mathrm{b}}$ & 0.66 & $80.33 \pm 5.51^{\mathrm{d}}$ & 92 & $857.67 \pm 73.53^{\mathrm{d}}$ & 67 \\
\hline
\end{tabular}

${ }^{1} 100 \mu \mathrm{L}$ (3:1) water and dimethylsulfoxide (DMSO). ${ }^{2} 0.5 \mu \mathrm{g}$ 4-nitroquinoline 1-oxide (4-NQO) for TA98 and 1.5

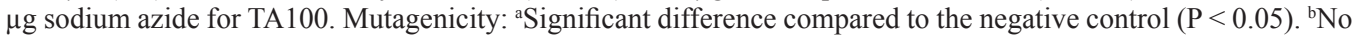
significant difference compared to the negative control $(\mathrm{P}>0.05)$. Antimutagenicity: ${ }^{\mathrm{N}}$ No significant difference compared to the positive control $(\mathrm{P}>0.05)$. ${ }^{\mathrm{d}}$ Significant difference compared to the positive control $(\mathrm{P}<0.05)$.

In the evaluation of mutagenicity, the doses of EESB tested (0.5, 1.0, 2.0 and $4.0 \mathrm{mg} /$ plate) did not cause an increase in the number of $\mathrm{His}^{+}$revertant colonies in either tester strain, TA98 or TA100, since no statistically significant difference was observed between the negative 
control group and any dose of EESB $(\mathrm{P}>0.05)$. Furthermore, none of the strains tested reached $\mathrm{MI} \geq 2$ or dose-response effect with EESB treatment, with the highest induction occurring for strain TA100, which reached MI $=1.12$ at the dose of $1.0 \mathrm{mg} / \mathrm{plate}$. The results of the Ames test demonstrated that EESB did not exhibit a mutagenic effect. Tester strains TA98 and TA100 exhibited an MI lower than with the negative control group $(\mathrm{MI}=1.00)$, at almost all doses, indicating that this extract possibly had a slight toxic effect against $S$. typhimurium cells.

The antimutagenic analyses demonstrated that at all doses tested $(0.5,1.0,2.0$ and 4.0 $\mathrm{mg}$ /plate) EESB showed a significant decrease in the number of $\mathrm{His}^{+}$revertant colonies in tester strains TA98 and TA100 compared with the respective positive controls $(\mathrm{P}<0.05)$. At the doses of $0.5,1.0,2.0$, and $4.0 \mathrm{mg} /$ plate, EESB showed an IP of 28, 44, 80 and $92 \%$ in strain TA98, and $42,44,54$ and $67 \%$ in strain TA100, respectively. These results demonstrated that EESB exhibited relevant antimutagenic action at all doses, but mainly at the dose of $4.0 \mathrm{mg} / \mathrm{plate}$, which produced an IP of 92 and $67 \%$, in TA98 and TA100, respectively. Therefore EESB was able to significantly protect DNA from the mutagens 4-NQO and sodium azide at all doses tested.

\section{Mouse bone marrow micronucleus test}

The results of the evaluation of EESB for genotoxic, cytotoxic, antigenotoxic, and anticytotoxic activity is shown in Table 2 .

Table 2. Frequency and means \pm standard deviation (SD) of micronucleated polychromatic erythrocytes (MNPCE) and means \pm SD of polychromatic and normochromatic erythrocyte ratio (PCE/NCE) observed in bone marrow of mice treated with different doses of the ethanolic extract from Lafoensia pacari stem bark (EESB) and co-treated with mitomycin $\mathrm{C}$ and their respective controls.

\begin{tabular}{|c|c|c|c|}
\hline \multirow[t]{2}{*}{ Sampling time, treatment } & \multicolumn{2}{|c|}{ MNPCE/2000 PCE } & \multirow{2}{*}{$\frac{\mathrm{PCE} / \mathrm{NCE}}{\text { Means } \pm \mathrm{SD}}$} \\
\hline & Individual data & Means \pm SD & \\
\hline \multicolumn{4}{|l|}{$24 \mathrm{~h}$} \\
\hline $\begin{array}{l}(\mathrm{C}-)^{1} \text { DMSO alone } \\
\text { EESB alone }\end{array}$ & $4,4,4,4,5$ & $4.2 \pm 0.45$ & $1.1 \pm 0.05$ \\
\hline $100 \mathrm{mg} / \mathrm{kg}$ & $4,5,3,4,3$ & $3.8 \pm 0.84^{\mathrm{a}}$ & $1.0 \pm 0.03^{\mathrm{b}}$ \\
\hline $200 \mathrm{mg} / \mathrm{kg}$ & $3,6,4,5,4$ & $4.4 \pm 1.14^{\mathrm{a}}$ & $0.9 \pm 0.02^{\mathrm{b}}$ \\
\hline $300 \mathrm{mg} / \mathrm{kg}$ & $8,7,5,6,8$ & $6.8 \pm 1.30^{\mathrm{b}}$ & $1.0 \pm 0.08^{\mathrm{b}}$ \\
\hline$(\mathrm{C}+)^{2} 4 \mathrm{mg} / \mathrm{kg}$ MMC & $34,32,33,30,34$ & $32.6 \pm 1.67$ & $0.55 \pm 0.06$ \\
\hline \multicolumn{4}{|l|}{$\mathrm{EESB}+4 \mathrm{mg} / \mathrm{kg} \mathrm{MMC}$} \\
\hline $100 \mathrm{mg} / \mathrm{kg}$ & $10,15,14,13,16$ & $13.6 \pm 2.30^{\mathrm{d}}$ & $0.80 \pm 0.09^{\mathrm{d}}$ \\
\hline $200 \mathrm{mg} / \mathrm{kg}$ & $12,11,14,14,16$ & $13.4 \pm 1.94^{\mathrm{d}}$ & $0.83 \pm 0.02^{\mathrm{d}}$ \\
\hline $300 \mathrm{mg} / \mathrm{kg}$ & $13,14,15,13,16$ & $14.2 \pm 1.30^{\mathrm{d}}$ & $0.75 \pm 0.04^{\mathrm{d}}$ \\
\hline \multicolumn{4}{|l|}{$48 \mathrm{~h}$} \\
\hline $\begin{array}{l}(\mathrm{C}-)^{1} \text { DMSO alone } \\
\text { EESB alone }\end{array}$ & $4,3,3,3,4$ & $3.4 \pm 0.55$ & $1.09 \pm 0.09$ \\
\hline $\begin{array}{l}\text { EESB alone } \\
100 \mathrm{mg} / \mathrm{kg}\end{array}$ & $4,3,2,3,3$ & $3.0 \pm 0.71^{\mathrm{a}}$ & $1.03 \pm 0.03^{\mathrm{a}}$ \\
\hline $200 \mathrm{mg} / \mathrm{kg}$ & $2,5,4,2,3$ & $3.2 \pm 1.30^{\mathrm{a}}$ & $1.07 \pm 0.03^{\mathrm{a}}$ \\
\hline $300 \mathrm{mg} / \mathrm{kg}$ & $6,5,4,5,4$ & $4.8 \pm 0.84^{\mathrm{b}}$ & $1.07 \pm 0.09^{\mathrm{a}}$ \\
\hline$(\mathrm{C}+)^{2} 4 \mathrm{mg} / \mathrm{kg} \mathrm{MMC}$ & $10,12,11,12,14$ & $11.8 \pm 1.48$ & $0.70 \pm 0.03$ \\
\hline \multicolumn{4}{|l|}{$\mathrm{EESB}+4 \mathrm{mg} / \mathrm{kg}$ MMC } \\
\hline $100 \mathrm{mg} / \mathrm{kg}$ & $8,9,8,9,10$ & $8.8 \pm 0.84^{\mathrm{d}}$ & $0.91 \pm 0.05^{\mathrm{d}}$ \\
\hline $200 \mathrm{mg} / \mathrm{kg}$ & $6,6,8,9,9$ & $7.6 \pm 1.52^{\mathrm{d}}$ & $0.83 \pm 0.02^{\mathrm{d}}$ \\
\hline $300 \mathrm{mg} / \mathrm{kg}$ & $6,10,8,6,8$ & $7.6 \pm 1.67^{\mathrm{d}}$ & $0.77 \pm 0.02^{\mathrm{d}}$ \\
\hline
\end{tabular}

${ }^{1}(\mathrm{C}-)=$ negative control group, dimethylsulfoxide $(\mathrm{DMSO}) .{ }^{2}(\mathrm{C}+)=$ positive control group, mitomycin $\mathrm{C}(\mathrm{MMC}$, $4 \mathrm{mg} / \mathrm{kg}$ ). All the results were compared with their respective control group at the respective time. ${ }^{\mathrm{a}}$ No significant difference compared with the $\mathrm{C}-(\mathrm{P}>0.05)$. ${ }^{\mathrm{b}}$ Significant difference compared with the $\mathrm{C}-(\mathrm{P}<0.05)$. ${ }^{\mathrm{c}}$ No significant

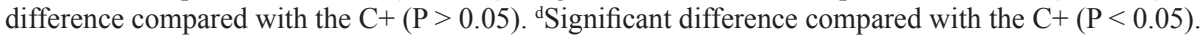


In this study, the negative control group (DMSO) showed low MNPCE values, as expected, and the positive control group showed a significant increase in MNPCE compared with the negative control group $(\mathrm{P}<0.05)$, confirming the sensitivity of the test.

In the genotoxicity analyses, the MNPCE frequencies in the groups that received 100, 200 , and $300 \mathrm{mg} / \mathrm{kg}$ were 3.8, 4.4, and 6.8 (per $2000 \mathrm{PCE}$ ) at $24 \mathrm{~h}$, and 3.0, 3.2, and 4.8 at 48 $\mathrm{h}$, respectively, whereas in the negative control group they were 4.2 at $24 \mathrm{~h}$ and $3.4 \mathrm{at} 48 \mathrm{~h}$. The doses of 100 and $200 \mathrm{mg} / \mathrm{kg}$ did not cause a significant increase in MNPCE frequency at 24 and $48 \mathrm{~h}$ compared with the negative control group $(\mathrm{P}>0.05)$, demonstrating the absence of genotoxic effects. The dose of $300 \mathrm{mg} / \mathrm{kg}$ caused a significant increase in MNPCE frequency at $24 \mathrm{~h}$ and $48 \mathrm{~h}$ compared with the respective negative control group $(\mathrm{P}<0.05)$, indicating a moderate genotoxic effect at this dose.

The PCE/NCE ratio can be an indicator of cytotoxicity. In the groups treated with 100, 200 , and $300 \mathrm{mg} / \mathrm{kg}$ EESB, the PCE/NCE ratios were 1.0, 0.9, and 1.0 at $24 \mathrm{~h}$, and 1.03, 1.07, and 1.07 at $48 \mathrm{~h}$, respectively, whereas in the negative control group they were 1.1 at $24 \mathrm{~h}$ and 1.09 at $48 \mathrm{~h}$. These results demonstrated that at $24 \mathrm{~h}$ the doses of 100, 200, and $300 \mathrm{mg} / \mathrm{kg}$ EESB caused a significant decrease in the PCE/NCE ratio compared with the negative control group $(\mathrm{P}<0.05)$, suggesting a slight cytotoxic effect at these doses. At $48 \mathrm{~h}$, all doses $(100,200$, and $300 \mathrm{mg} / \mathrm{kg}$ ) caused no significant decrease in the $\mathrm{PCE} / \mathrm{NCE}$ ratio $(\mathrm{P}>0.05)$ compared with the negative control group, indicating a lack of cytotoxic effect. Thus, EESB exhibited a slight cytotoxic effect only at $24 \mathrm{~h}$.

In the evaluation of EESB antigenotoxicity, the mean MNPCE values (per 2000 PCE) of the groups treated with 100,200 , and $300 \mathrm{mg} / \mathrm{kg}$ EESB + MMC were 13.6, 13.4 and 14.2 at $24 \mathrm{~h}$, and 8.8, 7.6 and 7.6 at $48 \mathrm{~h}$, respectively, whereas for the positive control group they were 32.6 at $24 \mathrm{~h}$ and 11.8 at $48 \mathrm{~h}$. At all doses, EESB caused a significant decrease in MNPCE frequency $(\mathrm{P}<0.05)$ compared with the positive control group. These results showed that EESB modulated the genotoxic activity of MMC at both times, demonstrating its antigenotoxic effect.

Regarding EESB anticytotoxic activity, the PCE/NCE ratios obtained at the doses of 100,200 and $300 \mathrm{mg} / \mathrm{kg}$ EESB + MMC were $0.80,0.83$ and 0.75 at $24 \mathrm{~h}$, and 0.91, 0.83 and 0.77 at $48 \mathrm{~h}$, respectively, whereas for the positive control group they were 0.55 at $24 \mathrm{~h}$ and 0.70 at $48 \mathrm{~h}$. A significant increase in PCE/NCE ratio was observed compared with the positive control group $(\mathrm{P}<0.05)$ at all doses of EESB combined with MMC, demonstrating that the simultaneous treatment attenuated the cytotoxicity of MMC.

\section{DISCUSSION}

The use of the in vitro Ames mutagenicity test in combination with the in vivo mouse micronucleus test has been recommended in several international guidelines to test the genotoxic/antigenotoxic potential of various types of substances (Vinod et al., 2011). Studies have demonstrated a correlation between the Ames test and carcinogenicity in rodents (Mortelmans and Zeiger, 2000).

The results of the mutagenic assessment of EESB revealed that all doses tested $(0.5$, $1.0,2.0$ and $4.0 \mathrm{mg} / \mathrm{kg}$ ) did not exhibit a mutagenic effect in $S$. typhimurium tester strains TA98 and TA100. In the mouse bone marrow micronucleus test, EESB did not exhibit genotoxic effect at the doses of 100 and $200 \mathrm{mg} / \mathrm{kg}$, but at the dose of $300 \mathrm{mg} / \mathrm{kg}$ a slight genotoxic effect was observed at 24 and $48 \mathrm{~h}$.

These results are in agreement with other studies performed with species of the family Lythraceae. Kirkland and Marzin (2003) reported that 2-hydroxy-1,4-naphthoquinone, a 
phenolic compound found in Lawsonia inermis leaves, showed a lack of mutagenicity in the Ames test, but caused a small increase in MNPCE frequency in the mouse bone marrow micronucleus test. Borade et al. (2011) demonstrated that L. inermis was not mutagenic using the Ames test and S. typhimurium tester strains TA98, TA100, and TA102 in the absence and presence of metabolic activation.

The results of the present study demonstrated that at almost all EESB doses tested exhibited an MI lower than that of the negative control group (MI =1.00) in S. typhimurium tester strains TA98 and TA100, indicating that it is possibly toxic to bacteria. In the mouse bone marrow micronucleus test, EESB exhibited a slight cytotoxic effect at all doses at $24 \mathrm{~h}$.

Studies on the toxicity of $L$. pacari demonstrated that the stem bark extract from this plant was not toxic at a dose of $5 \mathrm{~g} / \mathrm{kg}$ using a toxicity test in Wistar rats (Lago, 2004; Galdino et al., 2010) and in humans at the dose of $1.0 \mathrm{~g} / \mathrm{kg}$ in a clinical trial for the eradication of Helicobacter pylori (da Mota et al., 2006). However, several studies reported that various extracts from species of the family Lythraceae, such as Cuphea aequipetala (Avila et al., 2004), L. inermis (Borade et al., 2011) and Cuphea carthagensis (Elgindi et al., 2011), showed cytotoxicity. Galdino et al. (2010) demonstrated the presence of saponins in fractions of $L$. pacari stem bark. Podolak et al. (2010) reported that saponins possess cytotoxic activity, stimulate the apoptotic process, and cause cell cycle arrest and cytoskeleton disintegration in tumor cells. Thus, the mild cytotoxicity observed in the present study may be due, at least partially, to the action of saponins.

The carcinogenic agents 4-NQO and sodium azide were employed in the present study for the evaluation of the antimutagenic effect of EESB using the Ames test. 4-NQO induces intracellular oxidative stress, generating reactive oxygen species (ROS) and metabolic products that can bind to DNA, mainly to guanine residues, causing mutations (Kanojia and Vaidya, 2006). Sodium azide induces the generation of ROS when associated with the activity of caspases during the apoptotic process (Zhang et al., 2011) and causes point mutations in DNA(Al-Qurainy and Khan, 2009).

The chemotherapeutic agent MMC was used in the present study for the evaluation of EESB antigenotoxic and anticytotoxic effects, using the mouse bone marrow micronucleus test. MMC has genotoxic and cytotoxic effects mainly because it is an alkylating agent and causes ROS generation and apoptosis induction (Teus et al., 2009).

In the antimutagenicity evaluation by the Ames test, EESB showed relevant antimutagenic activity at all doses tested. In the mouse bone marrow micronucleus test, EESB also showed considerable antigenotoxic activity at all doses at 24 and $48 \mathrm{~h}$. These results demonstrated that EESB is a strong antimutagenic and antigenotoxic agent. The anticytotoxic activity of EESB was also evaluated by the mouse bone marrow micronucleus test, and the results showed that it modulated the cytotoxic action of MMC at all doses and times analyzed.

The phytochemical analysis of $L$. pacari stem bark revealed the presence of phenolic compounds, including flavonoids and tannins (Solon et al., 2000; Galdino et al., 2009). Previous studies have demonstrated that flavonoids and tannins have antioxidant activity, mainly due to their redox properties, absorbing or neutralizing free radicals that can attack biomolecules such as DNA (Degáspari and Waszczynskyj, 2004). Also, these compounds have antimutagenic and anticarcinogenic properties (Hodek et al., 2002).

Ellagic acid is an ellagitannin present in L. pacari and in several species of the family Lythraceae (Solon et al., 2000). According to Kannan and Quine (2012), ellagic acid possesses the abilities to attack free radicals and to protect the cells from lipid peroxidation and oxidative 
damage. This active constituent has also demonstrated antimutagenic effect in S. typhimurium tester strains TA98 and TA100 (Šmerák et al., 2002), as well as protective effects using the mouse bone marrow micronucleus test (Berni et al., 2012). Solon et al. (2000) reported that the extract from $L$. pacari stem bark has free radical scavenging activity and that ellagic acid is the main active compound present in this plant.

Probably, the antimutagenic, antigenotoxic, and anticytotoxic activities of EESB observed in the present study can be explained, at least partially, by the action of flavonoids and tannins (especially ellagic acid) present in this plant species.

In summary, the present results showed that EESB was not mutagenic according to the Ames test, but was moderately genotoxic only at the highest dose in mouse bone marrow cells and slightly toxic in the Ames test and the mouse bone marrow micronucleus test. EESB in combination with the respective positive control exhibited an antimutagenic action in bacteria, as well as antigenotoxic and anticytotoxic activities in mice, indicating that it is a strong protective agent against DNA damage.

\section{ACKNOWLEDGMENTS}

Research supported by Fundação de Amparo à Pesquisa do Estado de Goiás (FAPEG), Conselho Nacional de Desenvolvimento Científico e Tecnológico (CNPq), and Universidade Federal de Goiás (UFG).

\section{REFERENCES}

Al-Qurainy F and and Khan S (2009). Mutagenic effects of sodium azide and its application in crop improvement. World Appl. Sci. J. 6: 1589-1601.

Avila EV, Aguilar RT, Estrada MJ, Ortega ML, et al. (2004). Cytotoxic activity of Cuphea aequipetala. Proc. West Pharmacol. Soc. 47: 129-133.

Berni A, Grossi MR, Pepe G, Filippi S, et al. (2012). Protective effect of ellagic acid (EA) on micronucleus formation induced by $\mathrm{N}$-methyl-N'-nitro-N-nitrosoguanidine (MNNG) in mammalian cells, in in vitro assays and in vivo. Mutat. Res. 746: 60-65.

Borade AS, Kale BN and Shete RV (2011). A phytopharmacological review on Lawsonia inermis (Linn). Int. J. Pharm. Life Sci. 2: 536-541.

Claxton LD, Umbuzeiro GA and DeMarini DM (2010). The Salmonella mutagenicity assay: the stethoscope of genetic toxicology for the 21st century. Environ. Health Perspect. 118: 1515-1522.

da Mota MV, Atallah AN, Lapa AJ and Catapani WR (2006). Assessing the therapeutic use of Lafoensia pacari St. Hil. extract (mangava-brava) in the eradication of Helicobacter pylori: double-blind randomized clinical trial. Helicobacter 11: 188-195.

de Mesquita ML, de Paula JE, Pessoa C, de Moraes MO, et al. (2009). Cytotoxic activity of Brazilian Cerrado plants used in traditional medicine against cancer cell lines. J. Ethnopharmacol. 123: 439-445.

Degáspari CH and and Waszczynskyj N (2004). Propriedades antioxidantes de compostos fenólicos. Visão Acad. 5: 33-40.

Elgindi MR, Ayoub N, Milad R and Hassan R (2011). A comprehensive review of Cuphea (Lythraceae). Res. J. Pharm. Biol. Chem. Sci. 2: 847-885.

Ferreira FG, Regasini LO, Oliveira AM, Campos J, et al. (2009). Avaliação de mutagenicidade e antimutagenicidade de diferentes frações de Pterogyne nitens (Leguminosae), utilizando ensaio de micronúcleo em Tradescantia pallida. Rev. Bras. Farmacogn. 19: 61-67.

Galdino PM, Nascimento MV, Sampaio BL, Ferreira RN, et al. (2009). Antidepressant-like effect of Lafoensia pacari A. St.-Hil. ethanolic extract and fractions in mice. J. Ethnopharmacol. 124: 581-585.

Galdino PM, Nascimento MVM, Sousa FB, Ferreira RN, et al. (2010). Central activities of hydroalcoholic extract from Lafoensia pacari A. St.-Hil. stem bark. Braz. J. Pharm. Sci. 46: 455-462.

Hiruma-Lima CA, Santos LC, Kushima H, Pellizzon CH, et al. (2006). Qualea grandiflora, a Brazilian "Cerrado" 
medicinal plant presents an important antiulcer activity. J. Ethnopharmacol. 104: 207-214.

Hodek P, Trefil P and Stiborova M (2002). Flavonoids-potent and versatile biologically active compounds interacting with cytochromes P450. Chem. Biol. Interact. 139: 1-21.

Kannan MM and Quine SD (2012). Ellagic acid protects mitochondria from $\beta$-adrenergic agonist induced myocardial damage in rats; evidence from in vivo, in vitro and ultra structural study. Food Res. Int. 45: 1-8.

Kanojia D and Vaidya MM (2006). 4-nitroquinoline-1-oxide induced experimental oral carcinogenesis. Oral Oncol. 42: 655-667.

Kirkland D and Marzin D (2003). An assessment of the genotoxicity of 2-hydroxy-1,4-naphthoquinone, the natural dye ingredient of Henna. Mutat. Res. 537: 183-199.

Krishna G and Hayashi M (2000). In vivo rodent micronucleus assay: protocol, conduct and data interpretation. Mutat. Res. 455: 155-166.

Lago KM (2004). Estudos Preliminares Sobre o Potencial Toxicológico do Extrato Aquoso (Macerado e Decocto) de Lafoensia pacari St. Hil (Mangava-Brava). Undergraduate Term Paper, Faculdade de Farmácia, Universidade para o Desenvolvimento do Estado e da Região do Pantanal, Campo Grande.

Maron DM and Ames BN (1983). Revised methods for the Salmonella mutagenicity test. Mutat. Res. 113: 173-215.

Mazzolin LP, Nasser AL, Moraes TM, Santos RC, et al. (2010). Qualea parviflora Mart.: an integrative study to validate the gastroprotective, antidiarrheal, antihemorragic and mutagenic action. J. Ethnopharmacol. 127: 508-514.

Mortelmans K and Zeiger E (2000). The Ames Salmonella/microsome mutagenicity assay. Mutat. Res. 455: 29-60.

Nascimento VT, Moura NP, Vasconcelos MAS, Maciel MIS, et al. (2011). Chemical characterization of native wild plants of dry seasonal forests of the semi-arid region of northeastern Brazil. Food Res. Int. 44: 2112-2119.

Podolak I, Galanty A and Sobolewska D (2010). Saponins as cytotoxic agents: a review. Phytochem. Rev. 9: 425-474.

Ribeiro SC, Fehrmann L, Soares CPB, Jacovine LAG, et al. (2011). Above- and belowground biomass in a Brazilian Cerrado. For. Ecol. Manag. 262: 491-499.

Rogerio AP, Fontanari C, Borducchi E, Keller AC, et al. (2008). Anti-inflammatory effects of Lafoensia pacari and ellagic acid in a murine model of asthma. Eur. J. Pharmacol. 580: 262-270.

Sampaio BL, Bara MTF, Ferri PH, Santos SC, et al. (2011). Influence of environmental factors on the concentration of phenolic compounds in leaves of Lafoensia pacari. Rev. Bras. Farmacogn. 21: 1127-1137.

Santos FV, Nasser AL, Biso FI, Moreira LM, et al. (2011). Genotoxicity of polar and apolar extracts obtained from Qualea multiflora and Qualea grandiflora. J. Ethnopharmacol. 138: 105-110.

Sghaier MB, Bhouri W, Bouhlel I, Skandrani I, et al. (2011). Inhibitory effect of Teucrium ramosissimum extracts on aflatoxin B1, benzo[a]pyrene, 4-nitro-o-phenylenediamine and sodium azide induced mutagenicity: Correlation with antioxidant activity. S. Afr. J. Bot. 77: 730-740.

Silva Junior IF, Raimondi M, Zacchino S, Cechinel Filho V, et al. (2010). Evaluation of the antifungal activity and mode of action of Lafoensia pacari A. St.-Hil., Lythraceae, stem-bark extracts, fractions and ellagic acid. Rev. Bras. Farmacogn. 20: 422-428.

Silva CR, Vieira PM, Santos SC and Chen-Chen L (2012). Assessment of Duguetia furfuracea genotoxic and cytotoxic activity in bacteria and mice. An. Acad. Bras. Cienc. 84: 149-156.

Solon S, Lopes L, Teixeira de SP Jr and Schmeda-Hirschmann G (2000). Free radical scavenging activity of Lafoensia pacari. J. Ethnopharmacol. 72: 173-178.

Souza VR, Pereira PAP, Queiroz F, Borges SV, et al. (2012). Determination of bioactive compounds, antioxidant activity and chemical composition of Cerrado Brazilian fruits. Food Chem. 134: 381-386.

Šmerák P, Šestáková H, Polívková Z, Bárta I, et al. (2002). Antimutagenic effect of ellagic acid and its effect on the immune response in mice. Czech J. Food Sci. 5: 181-191.

Teus MA, de Benito-Llopis L and Alió JL (2009). Mitomycin C in corneal refractive surgery. Surv. Ophthalmol. 54: 487-502.

Vilar JB, Andrade LS, Leite KR, Ferreira HD, et al. (2009a). Assessment of genotoxicity and cytotoxicity of "lixeira" (Curatella americana L.) using the prophage $\lambda$ induction test (SOS inductest). Braz. J. Pharm. Sci. 45: 491-496.

Vilar JB, Leite KR and Chen CL (2009b). Antimutagenicity protection of Ginkgo biloba extract (Egb 761) against mitomycin $\mathrm{C}$ and cyclophosphamide in mouse bone marrow. Genet. Mol. Res. 8: 328-333.

Vinod V, Tiwari PK and Meshram GP (2011). Evaluation of mutagenic and antimutagenic activities of neem (Azadirachta indica) seed oil in the in vitro Ames Salmonella/microsome assay and in vivo mouse bone marrow micronucleus test. J. Ethnopharmacol. 134: 931-937.

von Ledebur M and Schmid W (1973). The micronucleus test. Methodological aspects. Mutat. Res. 19: 109-117.

Zhang L, Cheng XR, Hu JJ, Sun L, et al. (2011). Neuroprotective effects of hyperoside on sodium azide-induced apoptosis in PC12 cells. Chin. J. Nat. Med. 9: 455. 